Article

\title{
Exploratory Research for the Improvement of the Teaching of Spanish as a Second Language in a Spanish Public Center ${ }^{\dagger}$
}

\author{
Margarita Isabel Asensio Pastor ${ }^{1, *(1)}$ and Juan Pablo Carmona García ${ }^{2, *}$ \\ Department of Education, University of Almería, 4120 Almería, Spain \\ 2 Department of Spanish for foreigners, Official School of Languages of Granada, 18013 Granada, Spain \\ * Correspondence: masensiop@ual.es (M.I.A.P.); juanpablo@eoidegranada.org (J.P.C.G.) \\ + This work is linked to the R\&D project DIPURE (El discurso público sobre refugiados en España. Project \\ identification code: FFI2017-89147-R), granted by the Ministry of Economy, Industry and Competitiveness \\ (2018-2021) to the University of Almeria and whose main researcher is Antonio M. Bañón Hernández.
}

Received: 2 June 2019; Accepted: 6 November 2019; Published: 25 November 2019

\begin{abstract}
This paper is part of the R\&D project DIPURE (El Discurso Público sobre los Refugiados en España in English Public Discourse on Refugees in Spain) and it is one of the research lines of the research group "Andalusian Circle of Applied Linguistics, HUM-194" on the study of teaching Spanish as a second language (SSL) for immigrants and refugees. Its objective is to establish a profile of Spanish second language (SL) students at the Official School of Languages (OSL). To meet this objective, we carried out an exploratory study based on mixed quantitative-qualitative methods, including, among other methods, participant observation and a Likert-type questionnaire used with students of the OSL in Granada, from level A1 to B2. The data obtained has allowed us to reflect on the migration process in Spain and on the work in the classrooms of a public center with students who study Spanish as a second language- - their learning beliefs, needs, and attitudes, as well as didactic preferences. The information obtained is envisaged to improve the teaching practice of Spanish as a host language in a public educational context.
\end{abstract}

Keywords: refugees; immigrants; Spanish as a second language (SL); public center

\section{Introduction}

The increase in the number of migrants, whose figures are unprecedented in the history of migration, defines the current geopolitical situation worldwide. The document Global Trends (2017) of the United Nations High Commissioner for Refugees (UNHCR 2017) estimates that there are 65.6 million displaced people, of whom 22.5 million are considered refugees, 2.8 million are asylum seekers, and approximately 10 million are stateless.

In Spain, as Europe's southern border, the arrival of migrants has been a challenge for the host society, and in particular, for different public bodies, such as those responsible for the teaching of Spanish, who have had to adapt to the profile of a very heterogeneous population. The National Statistics Institute (INE ${ }^{1}$ ) estimates the number of foreigners in Spain on July 1, 2018, at 4,663,726 (INE 2018). The largest group is Moroccans with 692,379 people, followed by Romanians $(671,229$ people), British (280,669 people), Italians (231,157 people), and Chinese (185,746 people). These data are added to an ever-increasing number of refugees. According to data from the Spanish Ministry of

1 INE is the abbreviation in the Spanish language of Instituto Nacional de Estadística. 
the Interior, in the last ten years applications for international protection have increased by just over 150\% (Ministerio del Interior 2016).

Underlying these figures is the need to know how best to integrate and foster resilience among immigrants and refugees, and a fundamental aspect of this is the learning of Spanish. The work we report on in this article forms part of a broader research project, the R\&D project Public Discourse on Refugees in Spain (DIPURE), the aims of which are to find out more about the migratory process of refugees in Spain and to conduct applied linguistics research on the teaching and learning of Spanish as a second language (SSL). Furthermore, it is one of the research lines of the research group "Andalusian Circle of Applied Linguistics, HUM-194".

Regarding the teaching Spanish to migrants, in 2004, the Santander Manifesto (Villalba Martínez and Hernández García 2004), conceived of and disseminated by a group of experts from educational centers, NGOs, trade unions, adult centers, and universities in Spain, along with the Cervantes Institute, pointed to urgent and much-needed inclusion of the teaching of second languages in the framework of a global policy pertaining to immigrants and refugees. This policy considers not only the individual but also the family and the community to foster a sense of linguistic awareness when working with all the services that the host society provides. With this purpose, the key points of the Santander Manifesto are not only the need to create new teaching materials based on immigrants' own social and communicative needs, taking into account their different levels of training and personal qualifications, but also the need for the teaching of second languages (SL) to immigrants and refugees to be carried out by specialist teachers who can guarantee a high level of quality.

The Official School of Languages (OSL) of Granada, dependent on the Consejería de Educación from the Junta de Andalucía, is a public center for adults that is dedicated to the teaching of foreign languages, including Spanish. In the context of Spanish for foreigners, ${ }^{2}$ this center reflects to a great extent the migratory and demographic movements in Spain and in the region in which the OSL is located, namely Andalusia. One of the challenges is integrating and incorporating refugees and immigrants at risk of social exclusion into Spanish society, while trying to coordinate their work, as much as possible, with other centers dependent on independent bodies or NGOs, such as adult schools, community centers, trade unions, associations, occupational training centers, or religious centers.

This paper offers a profile of the student body (their beliefs, needs, and attitudes with respect to SSL), while at the same time serves to uncover more about the students' educational context, determine trends, identify variables, and serves as a starting point for further research; in this case, within OSL in Granada. This article is part of a large body of publications that have dealt with the inclusion of immigrants and refugees in education in Spain (Asensio Pastor 2016, 2018; Carmona García 2017, 2018; Níkleva 2014, 2017; García Parejo 2003; Hernández García and Martínez 1995, 2003, 2010; Moreno García 2004; Miquel López 1995, 2003; Larrañaga Domínguez 2003). The starting point of this research was to gather preliminary information to define problems and suggest hypotheses about these adult students to be applied to the curriculum and in the classroom for the development and improvement of relevant teaching practices.

This article is structured in six parts. After (1) the introduction, (2) we describe the legislative, structural, and organizational framework of the public school studied, within the framework of the Spanish educational system. (3) We offer an epistemological framework (4) and describe the methods used in relation to the participants and the phases of research. (5) We present the results from a questionnaire given to 40 students from level A1 to B2 along with supplementary material, which is

2 This is the generic term for the teaching of Spanish in the Official School of Languages, although in this respect we have taken the term "teaching Spanish as a second language", according to Santos Gargallo (1999, p. 21), in which Spanish comes to fulfil a social and institutional function within the linguistic community in which it is taught and learned, in opposition to what would be Spanish as a foreign language, which is learned in a context where there is no expectation of integration. In this sense, it is understood that an L2 is that which an immigrant and refugee learns due to the need for social inclusion in the new linguistic community in which they find themselves. 
the focus of the study. (6) The conclusions of this study are presented and discussed. In short, our aim is to give an account, by means of this exhaustive survey and other ethnographic instruments, of the teaching and learning of the host language (Spanish) in a public educational context and explore whether there are adequate teaching and organizational adaptations to address the needs of this group.

\section{Spanish Legislative Context and Educational System}

At the international level, the Geneva Convention, in its Refugee Statute, Article 1, Section A.2 (United Nations-UN- 1951), ratified in the New York Protocol relating to the Status of Refugees (UN 1967), defines refugees as people who are forced to leave their country of origin because they are persecuted (for reasons of race, religion, nationality, politics), without guarantees for their personal safety. Spain, for its part, developed its own legislation, adjusted to the previous guidelines, by means of law 12/2009 $\mathrm{BOE}^{3}$ - of 30 October 2009 (Jefatura del Estado 2009), and also includes the category of stateless people, defined as those who lack a nationality and find themselves in the situations mentioned above that make it impossible for them to return to their country. In this social and legislative context, the learning of Spanish is a central means of engagement with different spheres of social life in Spain and of regulated and public education on the part of the Spanish state in Andalusia. Spanish teaching to adult refugees and immigrants is conducted through two channels.

(1) The centers and sections of permanent education (CEPER and SEPER in Spanish), created by Decree 196/2005 on September 13 (Junta de Andalucía Consejería de Educación 2005), in which basic education is provided, ranging from functional literacy to preparation for obtaining a basic qualification and access to other educational levels. These centers currently receive some 100,000 people over the age of 18 in Andalusia, where classes are taught by around 2000 teachers. The teaching of Spanish to refugees and immigrants appears as part of basic teaching qualifications under "Interculturality, Culture, and Spanish as a Foreign Language".

(2) The Official Schools of Languages, framed in Special Regime Teaching in article 60.2 of the Education Law 2/2006 of May 3 (Jefatura del Estado 2006), where it is specified that: "the official language schools shall especially promote the study of the official languages of the Member States of the European Union, of the co-official languages existing in Spain and of Spanish as a foreign language". In Andalusia, the OSL is regulated by Decree 15/2012 of February 7 (Junta de Andalucía Consejería de Educación 2012a), which approves the organic regulation of official schools of languages in the autonomous community of Andalusia.

The Official Schools of Languages have adopted the system of levels of linguistic competence developed by the Council of Europe (2002) in the Common European Framework of Reference (CEFR): Access (A1), Platform (A2), Threshold (B1), Advanced (B2), Effective Operational Proficiency (C1), and Mastery (C2). They have also assumed the evaluation criteria and the systems of accreditation and certification of language knowledge with respect to previous levels: basic, intermediate, and advanced. The Order of October 18, 2007, BOJA ${ }^{4}$ of November 14 (Junta de Andalucía Consejería de Educación 2007), developed the curriculum corresponding to special regime language teaching in Andalusia and established the levels to the CEFR ${ }^{5}$, as illustrated in Table 1 :

BOE is the abbreviation in the Spanish language of Boletín Oficial del Estado.

BOJA is the abbreviation in the Spanish language of Boletín Oficial de la Junta de Andalucía.

From the academic year 2018-2019 and according to Instruction 12/2018 of September 4 (Junta de Andalucía Consejería de Educación 2018), of the Department of Educational Planning on the Ordination and Curriculum of the Official Schools of Languages of the Special Regime, following the R. D. 1041/2017, December 22 (Jefatura del Estado 2017), the name of these courses has changed: Basic 1 = 1st Basic Level, Basic $2=2$ nd Basic Level, Intermediate = Intermediate B1, Advanced $1=1$ st Intermediate B2, Advanced 2 = 2nd Intermediate B2, Level C1 = 1st Advanced C1. In the new curriculum, Level C1 has one more course: 2nd Advanced C1. 
Table 1. Official Schools of Language (OSL) levels, courses, and Common European Framework of Reference (CEFR) levels.

\begin{tabular}{ccc}
\hline OSL Levels & OSL Courses & CEFR Levels \\
\hline \multirow{2}{*}{ Basic Level } & Basic 1 & A1 \\
& Basic 2 & A2 \\
\hline Intermediate Level & Intermediate & B1 \\
\hline \multirow{2}{*}{ Advanced Level } & Advanced 1 & B2.1 \\
& Advanced 2 & B2.2 \\
\hline Level C1 & C1 & C1 \\
\hline
\end{tabular}

These four levels are distributed across six courses of approximately $140 \mathrm{~h}$ ( 4.5 hours per week). Depending on the organization of the center, the on-site Spanish courses for levels A1-B2 can be divided into intensive courses of nine hours per week (from September to January or from February to June) or extensive (from September to June). Learners also have the option of enrolling as free students in the month of April and can only attend the certification exams (Basic 2, Intermediate, and Advanced 2) in the June or September exams.

Access by students to the OSL was established by the order on 20 April 2012 (Junta de Andalucía Consejería de Educación 2012b), which regulates the criteria and procedures for admitting students. This order specifies the age requirements (16 years of age in the calendar year in which the place is applied for). Likewise, a scale exists by which students can obtain points for the income received the year before they apply for a place and for their employment situation. The maximum number of students permitted is 30 for levels A1 to B1 and 25 for levels B2 to C1.2.

\section{Epistemological Framework}

The teaching and learning of Spanish to immigrants and refugees in Spain dates back to pioneering work by Mateo García (1995) and Miquel López (1995, 2003), which although it is centered on teaching adults, also included generic overviews and sources on intercultural aspects of immigration (Hernández Sacristán and Marco 1997), sociolinguistics of immigration (García Marcos 2002), and acquisition of second languages (Salazar García 2004). Slagter (1994) tabulated expectations and attitudes in the process of learning second languages. Other authors have focused on different motivation of foreign vs. second language learners, how this relates to daily life, the social function learning plays, and what the influence of institutional or family environments is (Díaz-Corralejo Conde 2001; Moreno García 2004; Muñoz 2002; Muñoz López 2004; García Marcos 2018). For immigrants and refugees, these aspects of the acquisition process play a determining role in the integration and relate to their activity in the host community.

Added to the above is the recognition that a refugee needs to integrate into a social environment where protection is more important than welcome. Several studies indicate that refugees may experience post-traumatic stress disorder (Kleinmann 1984; Hayward 2007). For Kleinmann (1984, p. 210); all migration, including voluntary migration, is a traumatic experience because there is a vital, social, and identity imbalance when leaving one's community. Hayward (2007) talks about three main stressful factors for the migrant in a new community: the migratory factor (relative to the trip itself), the cultural factor (when facing a new culture), and the traumatic factor (abandonment of home, difficulty in finding new destination). In addition to these factors, there are others that depend on these, such as the economic or family situation.

On the other hand, in the acquisition or learning process for refugees and immigrants, it is foreseeable that other factors indicated by linguistics applied to language teaching will intervene (Larsen-Freeman and Long 1991; Santos Gargallo 1999; Pastor Cesteros 2004; Griffin 2005; García Marcos 2018). These factors include age (children, youth, or adults), monolingual vs. multilingual background (with familiarity with the simultaneous development of several communicative skills in 
their own community), gender, and degree of education. There is no doubt that previous experience in learning a foreign language in the education system has a highly positive influence on the subsequent deployment of communicative skills in learning another language. On the other hand, the degree of education relates to demands on learners as students and to the linguistic, socio-cultural, and pragmatic content of education. This, in turn, affects teachers' choices, including classroom dynamics, such as learning styles, the rhythm of teaching sessions, the use of metalanguage, the preference for communicative skills and abilities, expectations about teaching practice, or the need for specific pedagogical materials. Likewise, the source language introduces important conditions at two levels:

- Firstly, the typological distance between the source language and the target language is decisive for new language acquisition. The sequence of learning is accelerated for related languages, but the learner's perceptual discrimination can be strengthened when the two languages are typologically distant.

- Secondly, the learner's writing system can also be decisive, not only in terms of direction and graphemes, but also in terms of the level of metalinguistic knowledge that the learner has in relation to how their language and the host language are written.

There are, without a doubt, other factors which have an influence to a greater or lesser degree, such as the cognitive style of the student body, the aforementioned needs and expectations, cultural background, or past experiences. Here, there are two observations that point to the possible uniqueness of teaching refugees. If the characteristic of heterogeneity is consubstantial in all the teaching of non-native languages, this assumption multiplies exponentially in a classroom of refugees. On the other hand, in a foreign language classroom it is not uncommon for students to operate within groups of the same origin, even within previously established and regulated programs. In the teaching of second languages to refugees, this process is more complex due to other conditioning factors beyond mere groupings by age, geographical origin, or mother tongue. While it is the case that in the reception centers there is the possibility of working with linguistically homogeneous groups, this is a provisional solution, which in the medium term, has to lead to the beginning of integration in the receiving society, membership in wider groups, and consequently, to more linguistic diversification within the classroom. A second circumstance must be added here-the refugee's inclusion in the host communities (García Ortiz and Ruiz-Zorrilla 2013). Even if refugees form groups based on social and linguistic origin, these will be made up of those with different arrival times, and naturally, with different degrees of acquisition of the host language. This should be kept in mind by the teacher, as it may be difficult to schedule the class.

With regard to refugees, it should be noted that none of the above factors is a direct consequence of, or a result of, refugee status. These are universal factors that condition linguistic action, in a broad and encompassing sense, from acquisition processes to the social stratification of languages. In addition, they do not affect processes in a uniform way among that group but are conditioned and act in relation to other elements.

To conclude this section, two main features can be outlined that delimit assumptions about the teaching and learning of Spanish as a non-native language. Firstly, the learner's personal history, including coming from a traumatic situation, can benefit from integration, which is seen as the development of self-esteem, increase in resilience, and capacity to overcome challenges (Chadwik and Awad 2016; Capstick and Delaney 2017). In this aspect, teachers' positive and receptive attitudes are fundamental, not only in the classroom but for support in interacting with the host society. Secondly, what should constitute the key work with this group of students is not so much the curricular content as it is sequences of learning, objectives, materials, and classroom processes that are appropriate to their needs. In other words, it is justified to modify the curriculum if it does not benefit these learners. The communicative approach, in all its variants, is the most recommended because it places the development of communicative competence at the center of learning, as well as emphasizing the skills and abilities of the learner. 


\section{Methodology}

As already indicated in the introduction to this article, we offer an exploratory study of Spanish as a second language (SSL) students at the OSL in Granada. In order to do so, we followed a mixed qualitative-quantitative research methods approach, the use of which we detail in the following sections, along with a description of the characteristics of the participants.

\subsection{The Participants}

The participants in the study were students of SSL of the OSL in the academic year 2017-2018 and enrolled in the five levels that this center offers: Basic 1, Basic 2, Intermediate, Advanced 1, and Advanced 2, equivalent to levels A1 to B2 according to the CEFR (Council of Europe, 2002) ${ }^{6}$. During that academic year, there were 115 students enrolled and distributed among the different courses, as shown in the graph below.

However, the total number of participants in this study varied depending on the phase of research: in the first phase involving participant observation, all 115 students participated, while in the questionnaire phase only 40 students (38.78\%) completed it. We assume this is due to the voluntary nature of participation and when it was distributed $38.78 \%$ ). Thus while the total number of students constitutes an good-sized sample across the five courses as shown in Figures 1 and 2, the lower numbers of students completing the questionnaire reflects one of the realities of an educational system where challenges relating to students' daily lives result in often legitimate absences.

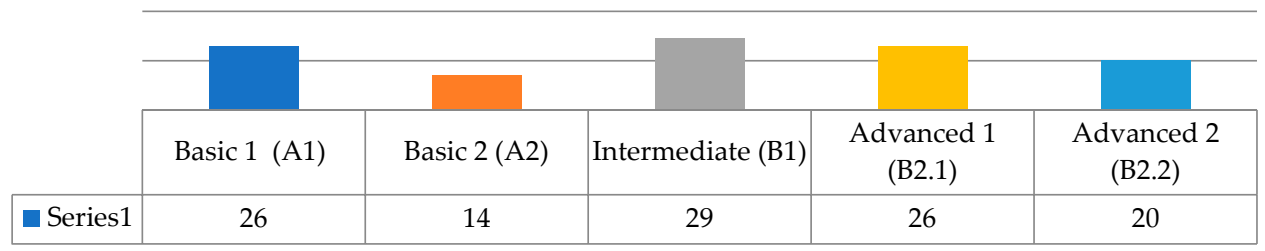

Figure 1. Students enrolled in the 2017-2018 academic year at the OSL of Granada.

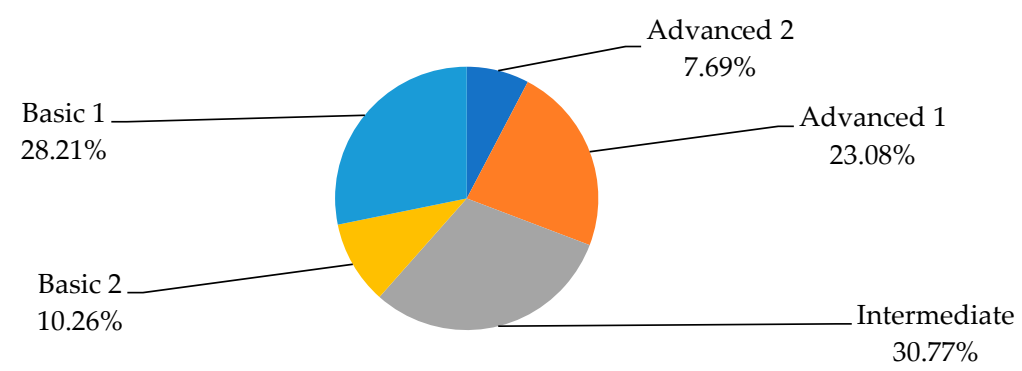

Figure 2. Percentage of participants by level.

As for the percentage distribution of the participants, the greatest number of these are found among Intermediate level students (30.77\%), followed by Basic $1(28.21 \%)$ and Advanced $1(23.08 \%)$.

With respect to their origin, it is heterogeneous and reflects the characteristic reality of the OSL of Granada, and to a large extent, the migratory and demographic movements in Granada, Andalusia, and Spain in recent years. Students of Arab origin, but from a range of countries, predominate $(42.50 \%)$. On the other hand, the 40 respondents can be grouped into four categories that also represent the set of enrolled students: resourceful foreigners, immigrants, refugees or asylum seekers, and scholarship holders. These categories can be extrapolated to the total number of students.

6 All subjects gave their informed consent for inclusion before they participated in the study. The study was conducted in accordance with the Declaration of Helsinki, and the protocol was approved by the Ethics Committee of DIPURE (Project identification code: FFI2017-89147-R). 
In the case of the category of foreigners with resources, examples are those coming from European countries such as the Netherlands or Ireland, or from the United States. On the other hand, the group formed by immigrants is the majority among the 155 students enrolled, especially those of Moroccan origin, although in the sample they are behind the last group. On the other hand, the category of refugees and asylum seekers also exists (e.g., Ukrainian students), with a low representative presence amongst the number of non-Spanish-speaking refugees in Spain. Finally, we have established a fourth category, that of foreigners with a scholarship to study at the University of Granada, generally for a master's degree or doctorate.

As can be seen from the above, this is a heterogeneous group, as illustrated in Figure 3, in which communication needs and priorities are diverse, ranging from interaction with the receiving community to being able to resolve administrative issues.

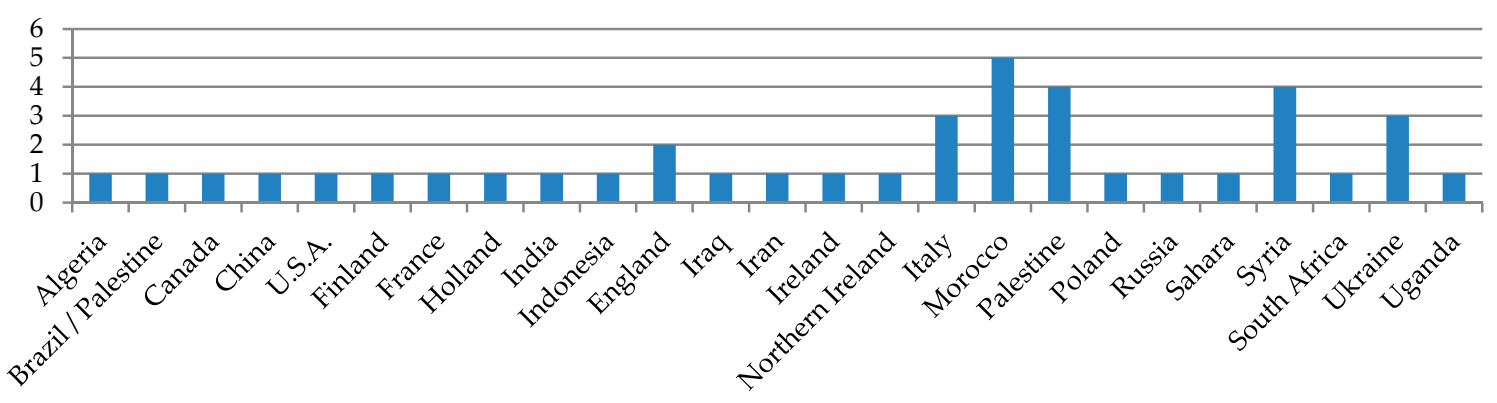

Figure 3. Origin of the participants.

\subsection{Study Design}

The study took a mixed-methods approach, using both quantitative and qualitative instruments, which were implemented according to the phase of research, those is summarized in Table 2. This was driven by the direct interaction in the classroom between teacher and student, through the participants' own observation. In this sense, as Angrosino (2012, p. 35) reminds us, the ethnographic work is the art and science of describing a human group: its institutions, interpersonal behaviours, material productions, and beliefs. This first phase led to the second phase, which involved a qualitative valuing survey to provide us with both biographic and linguistic information about the participants and evaluative data on the teaching of Spanish at the OSL in Granada (Richards and Rodgers 2003). In this way, it was possible to establish a profile to inform curricular adaptations and changes in the classroom decisions based on the assumptions of communicative approaches. The observation data motivated the design of the questionnaire. Before it was distributed, a panel of experts evaluated it. It was then piloted with a random sample of ten students, two for each level of Spanish. After the evaluation of the experts and the pilot, recommended changes were made, and the questionnaire was then distributed to all 115 students who were invited to complete it on a voluntary basis. In order to facilitate distribution, the questionnaire was distributed in digital form, placed in the virtual teaching platform (Edmodo) used by the OSL of Granada and carried out through the Google Forms.

Table 2. Phases of the investigation.

\begin{tabular}{ll}
\hline Phase I & Participant observation and field diary entries about student needs, beliefs, etc. \\
\hline Phase II & Preparation of the first questionnaire based on data from the previous phase. \\
\hline Phase III & $\begin{array}{l}\text { After the design of the survey it was submitted for evaluation and validation by experts. } \\
\text { It was subjected to a pilot with a random selection of ten students from the five levels. }\end{array}$ \\
\hline Phase IV & $\begin{array}{l}\text { Analysis of the first results of the pilot survey. Correction of the questionnaire and full } \\
\text { distribution. }\end{array}$ \\
\hline Phase V & Analysis data and conclusions. \\
\hline
\end{tabular}


As for the structure of the survey, it consisted of three blocks (see Appendix A): block I, control information (identifying); block II, beliefs and needs regarding the learning of SSL; and block III, aspects of teaching SSL in the classroom. The first block was qualitative and focused on biographic information about the participant, such as gender, age, and nationality, as well as linguistic information about the participant and how long they had been in Spain and their situation in the country (with or without refugee or asylee status, there for studies, for work, etc.); while the second and third blocks were of a quantitative, non-experimental, descriptive nature (McMillan and Schumacher 2011, p. 42). The second block was aimed at the beliefs and needs that students expressed about learning Spanish as a second language. The third block was aimed at the process of teaching and learning Spanish, specifically aspects of teaching in the classroom. For the last two blocks, a Likert scale (1 to 7) was used because of its value-descriptive character, as it best measured the attitudes, beliefs, or educational needs of these students: "the interviewee shows agreement or disagreement with the statement" (McMillan and Schumacher 2011, p. 242).

\section{Data Analysis}

From the classroom observation data, the diversity of the enrolled students stands out when compared to students in classes for the other languages taught in the OSL. This shows that the Spanish classroom is a meeting place for students from different places of origin, mother tongues, cultures, beliefs, levels of previous training and learning styles, legal or work situations, different plans for the future, and economic difficulties. This type of student body is socio-politically labelled as foreigner, as immigrant, as refugee, as asylum seeker, as illegal. In any case, the observation data indicates that all of them find in Spanish the gateway not only to Spanish culture and society, but to the labor, training, or cultural markets. This diversity is a challenge for the teacher.

These observation data provided us with information to prepare a questionnaire, which, as already described in the previous section, was divided into three blocks. Because this was our quantitative measure, we took a number of steps. First, validity was judged by five experts who were professors specializing in teaching Spanish as a foreign language: one from the OSL of Malaga, one from the University of Almeria, one from the University of Granada, one from the University of Alexandria, and one from the Cervantes Institute of Moscow. They were provided with the objectives of the questionnaire, its content, and associated items. The modifications they recommended were division of the questionnaire into three blocks and the elimination of some questions, such as the classification of the knowledge of an SL (distinct from Spanish) according to the skills of speaking, understanding, reading, and writing, so as not to deviate from the ultimate purpose of the research, since it was not our objective to analyze the variables of knowledge of another language and how this affects the learning of Spanish. The question about the student's city or town of origin was also discarded, leaving only their nationality. In addition, two items were eliminated: one relating to the student's current level of Spanish, because this was already known within the program, and the other asking about studying Spanish upon arrival in Spain or another Spanish-speaking country, because the answer could be deduced from another item on the questionnaire

For reliability, especially concerning blocks II and III based on the Likert scale, the internal consistency of the items was analyzed by calculating the Cronbach alpha coefficient, which gave a score of 0.92 , above the minimum acceptability limit (Hair et al. 1999). Taking into account the homogeneity index $<0.2$, we were able to dispense with one item, although a new reliability analysis gave the same Cronbach alpha coefficient.

Now we turn to the analysis of the data.

\section{Block I: Control Information}

The 40 participants who completed the questionnaire were $57.5 \%$ female and $42.5 \%$ male, with an average age of 36.56 years (minimum 20 years, maximum 70 years) of various nationalities, although the largest group was Moroccans with $12.5 \%$, followed by Palestinians and Syrians with $10 \%$ each, and 
Ukrainians and Italians with 7.5\%. From the point of view of gender, the number of Moroccan women stands out over the rest. The distribution of participants by gender and nationality is shown in the following graph (Figure 4).
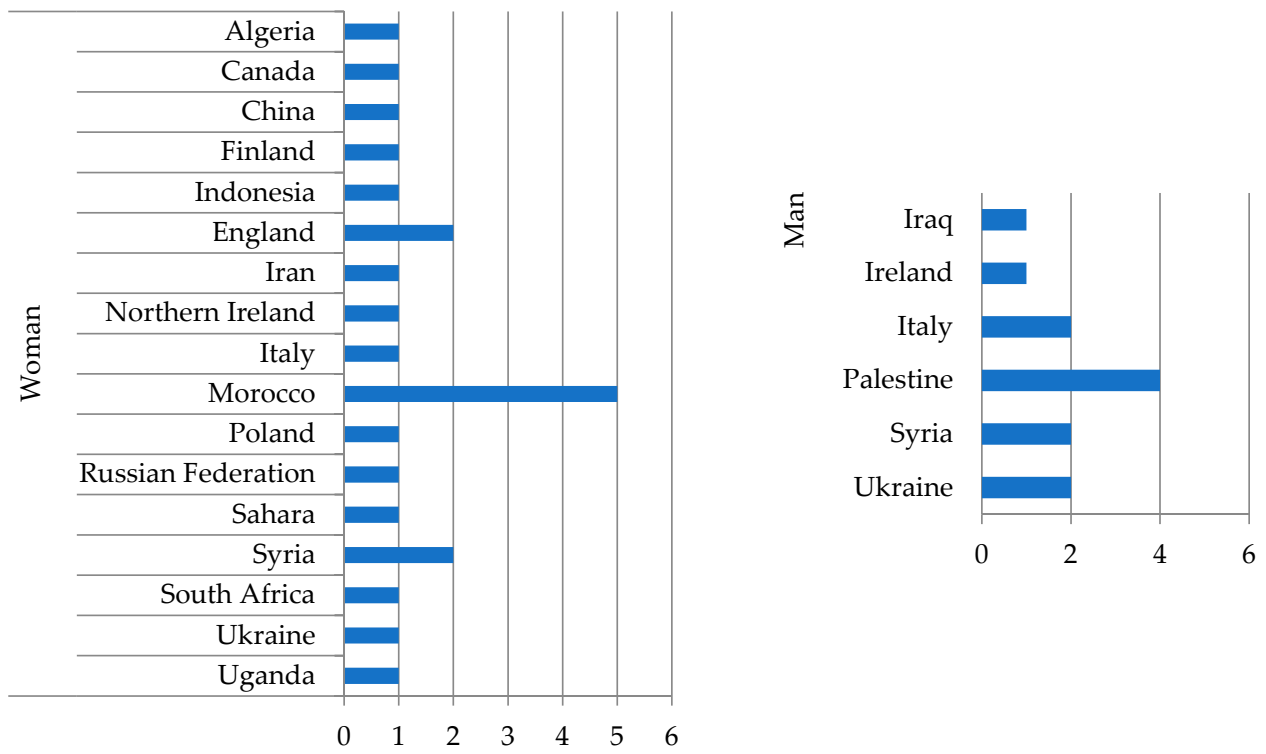

Figure 4. Distribution between genders and nationalities.

The majority of participants were mostly university students (60\%)-a sector made up mainly of women $(58.33 \%)$, while $20 \%$ had professional training, $17.5 \%$ had secondary education, and $2.5 \%$ had primary education. Of these, slightly less than half of those surveyed were either unemployed ( $27.5 \%, 80 \%$ of whom were women) or students $(25 \%, 55.56 \%$ of whom were men). That is summarized in Table 3.

Table 3. Students' gender-studies-profession.

\begin{tabular}{cccc}
\hline Gender & Studies & Work & No. \\
\hline Woman & University & Employee & 1 \\
\hline & Entrepreneur (self-employed) & 2 \\
\hline & Student & 3 \\
\hline & Teacher & 3 \\
\hline Vocational Training & No job & 5 \\
\hline & Housewife & 2 \\
\hline & Teacher & 1 \\
\hline & Necondary & Nuxiliary home help & 1 \\
\hline & Student & 1 \\
\hline & Primary & No job & 2 \\
\hline
\end{tabular}


Table 3. Cont.

\begin{tabular}{cccc}
\hline Gender & Studies & Work & No. \\
\hline Man & University & Student & 4 \\
\hline & Industry and factories & 1 \\
\hline & Lecturer & 1 \\
\hline & Teacher & 1 \\
\hline Vocational Training & Priest & 1 \\
\hline & No job & 2 \\
\hline & Student & 1 \\
\hline & Retired & 1 \\
\hline & Pizza maker & 1 \\
\hline & Necondary & Ndministrative (HR) & 1 \\
\hline & Entrepreneur (self-employed) & 1 \\
\hline & Student & 1 \\
\hline
\end{tabular}

In addition, the majority of students came from monocultural families (52.5\%) as opposed to those who claimed to have a mixed family $(47.5 \%)$.

As shown in Figure 5, the main mother tongue was Arabic (34.88\%), followed by English (20.93\%). In total, $80 \%$ of the Arabic-speaking respondents said they knew another language or other languages, and in some cases said they were bilingual (three participants). This was not the same for English speakers, where only $14.29 \%$ said they were fluent in a second language.

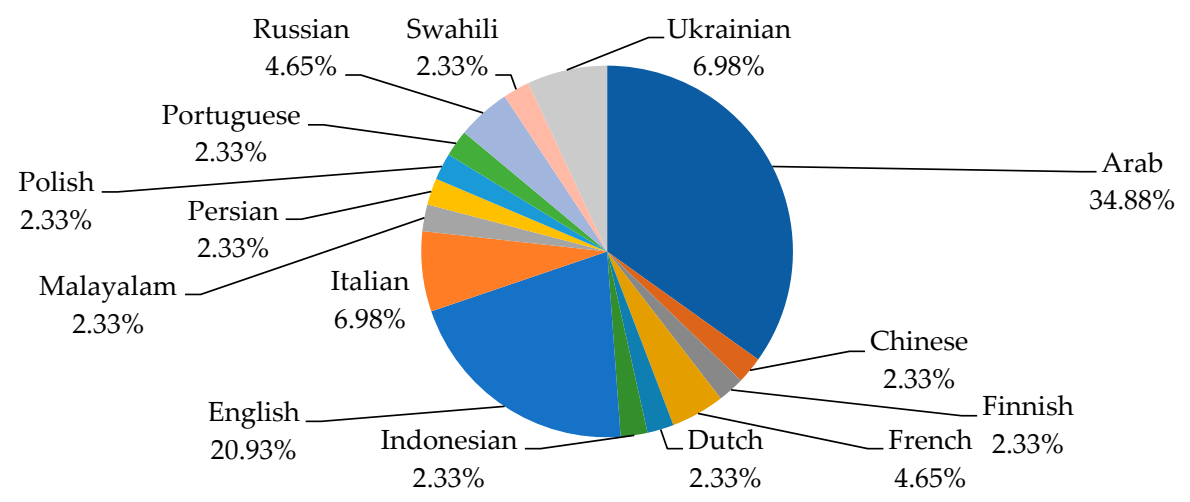

Figure 5. Languages of the students.

Ultimately, on Q.I.9., "What other foreign languages do you know and can you use fluently?", participants who expressed fluency in one or more additional language accounted for $75 \%$, with English being the main language (52.17\%), followed by French $(15 \%)$ and German $(11 \%)$. These percentages exclude native or bilingual speakers.

Of these participants, $52.27 \%$ had only lived in Spain since they left their countries of origin, which means that Spain can be considered as the first migratory destination; $18.18 \%$ had lived in another country and $29.55 \%$ had lived in two other countries. Furthermore, $48.72 \%$ of the participants had resided in Spain for one year, followed by those with five years of residence (35.90\%) and by those with up to ten years of residence (7.69\%), as illustrated in Figure 6. 


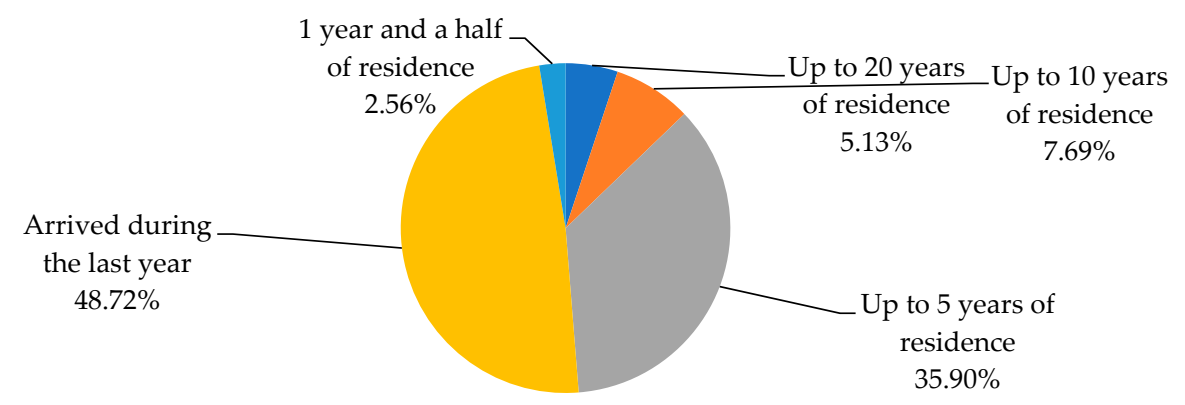

Figure 6. Time of residence in Spain.

The fact that these students decide to study at the OSL already shows their intention to stay in the country, because the course runs for a full academic year. This differs from other centers that offer intensive courses, focused on those who come to take a Spanish course and return home to their country. Likewise, we observe students who had been living in Spain for some time and who had finally decided to enroll at the OSL in Granada in order to obtain a certificate for legal reasons, such as for citizenship. OSL degrees are recognized as confirming language proficiency for this purpose.

In relation to the above, $42.5 \%$ of the respondents had been studying Spanish for less than a year, divided between Basic 1, Basic 2, and Intermediate levels. Likewise, $85 \%$ of those enrolled had not previously studied Spanish before enrolling in the OSL. In the Figure 7 is illustrated it.

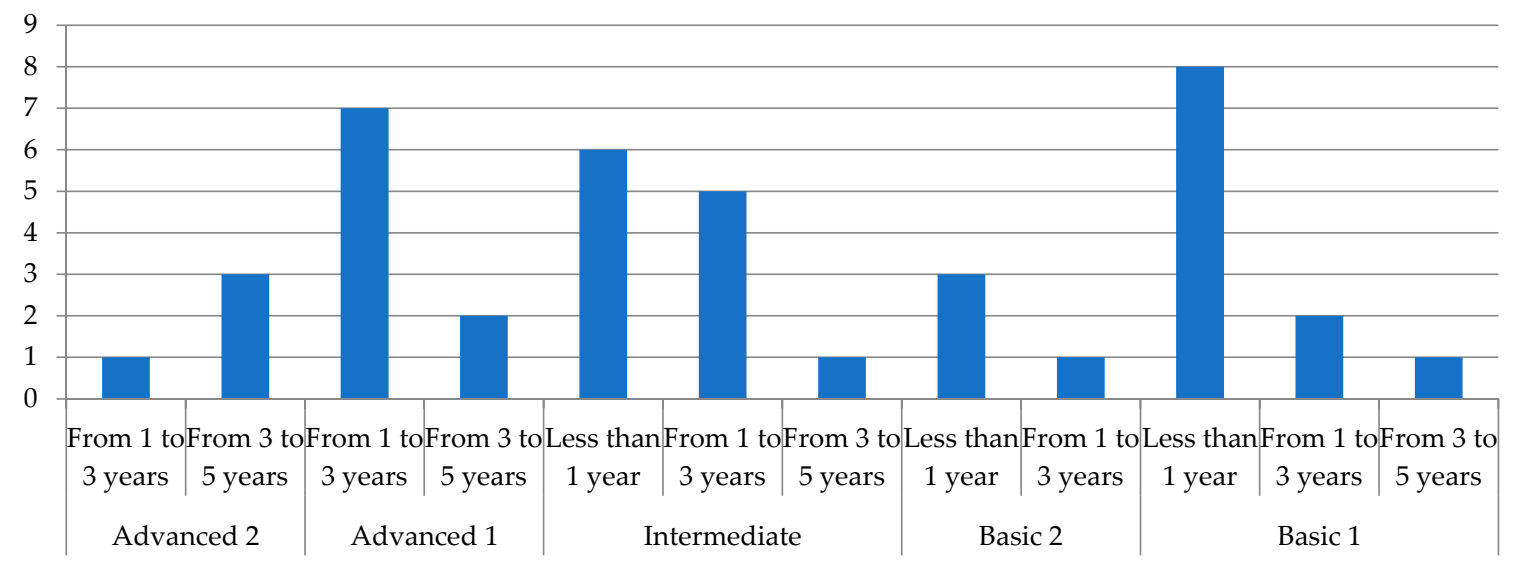

Figure 7. Time spent studying Spanish.

Finally, given that the study focused on the OSL in Granada, we considered it appropriate to find out how the participants knew of its existence. The answers show how information networks work in the non-Spanish student body, and this turned out to be eminently social, since the majority found out about it through friends (56.10\%), followed by relatives (34.15\%). Far fewer found out about it through a Spanish organization or through the website ( $4.88 \%$ each), as can be summarized in Figure 8. 


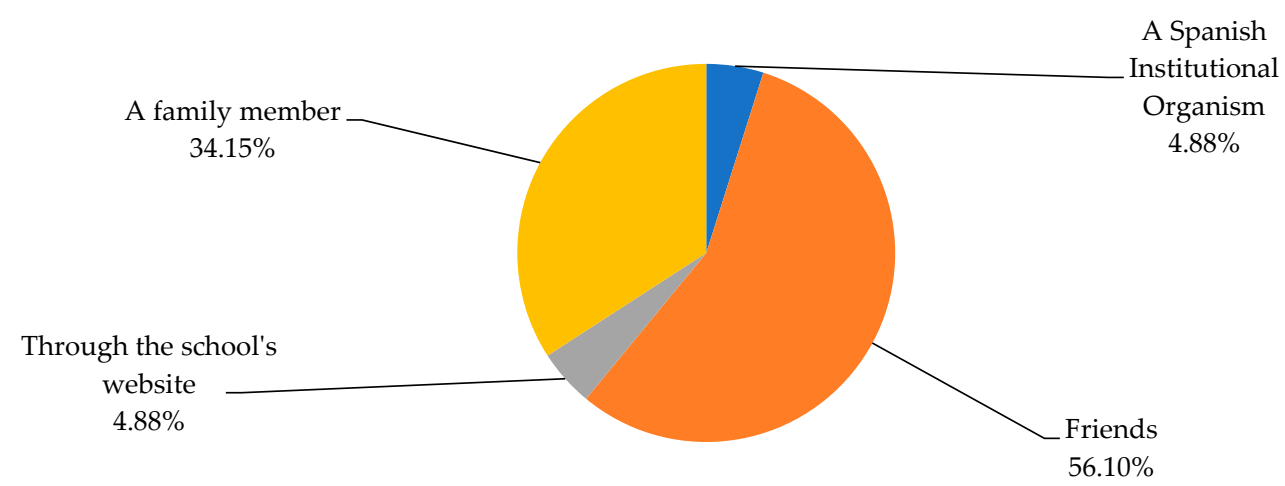

Figure 8. Awareness of the OSL.

Block II: Learning Spanish as second languages

In this block, we asked participants to assess their needs, purpose, and expectations for studying Spanish. These questions correspond to three items, which were divided, in turn, into several sub-items and which yielded the results shown below, with the question numbers and the questions in their English translation included (the questionnaire was in Spanish), as illustrated in Table 4.

Table 4. Survey Block II data.

\begin{tabular}{|c|c|c|c|c|c|c|}
\hline \multicolumn{7}{|c|}{ BLOCK II. Learning Spanish as second language } \\
\hline \multicolumn{7}{|c|}{$\begin{array}{l}\text { Q.II.1. Why do you think you need to learn Spanish? Value from } 1 \text { (total disagreement) to } 7 \text { (total } \\
\text { agreement) }\end{array}$} \\
\hline & No. & Min. & Max. & Mean & $\begin{array}{l}\text { Std. } \\
\text { Deviation }\end{array}$ & $\begin{array}{l}\text { Correlation } \\
\text { (homogeneity } \\
\text { index) }\end{array}$ \\
\hline $\begin{array}{l}\text { Q.II.1.1 I think Spanish is convenient in } \\
\text { order to find a good job }\end{array}$ & 40 & 1 & 7 & 4.8 & 2.16 & 0.57 \\
\hline $\begin{array}{l}\text { Q.II.1.2 I consider that Spanish is } \\
\text { convenient to be able to relate to other } \\
\text { people who live in this country }\end{array}$ & 40 & 1 & 7 & 6.05 & 1.47 & 0.63 \\
\hline $\begin{array}{l}\text { Q.II.1.3 I consider that Spanish is } \\
\text { convenient to be able to study (yourself, } \\
\text { your children, your relatives and } \\
\text { acquaintances) }\end{array}$ & 40 & 1 & 7 & 5.13 & 1.99 & 0.64 \\
\hline $\begin{array}{l}\text { Q.II.1.4 I consider that Spanish is } \\
\text { convenient to understand doctors and } \\
\text { nurses }\end{array}$ & 40 & 1 & 7 & 5.1 & 2.10 & 0.77 \\
\hline $\begin{array}{l}\text { Q.II.1.5 I consider that Spanish is } \\
\text { convenient to be able to go shopping }\end{array}$ & 40 & 1 & 7 & 5.48 & 1.84 & 0.32 \\
\hline $\begin{array}{l}\text { Q.II.1.6 I consider that Spanish is } \\
\text { convenient to be able to manage my } \\
\text { papers and go to the administration }\end{array}$ & 40 & 1 & 7 & 5.13 & 1.95 & 0.67 \\
\hline $\begin{array}{l}\text { Q.II.1.7 I consider that Spanish is suitable } \\
\text { for higher education }\end{array}$ & 40 & 1 & 7 & 4.73 & 2.10 & 0.60 \\
\hline $\begin{array}{l}\text { Q.II.1.8 I believe that Spanish is } \\
\text { convenient for me to understand my } \\
\text { son/daughter's teacher }\end{array}$ & 40 & 1 & 7 & 4.48 & 2.33 & 0.73 \\
\hline
\end{tabular}


Table 4. Cont.

\begin{tabular}{|c|c|c|c|c|c|c|}
\hline \multicolumn{7}{|c|}{ Q.II.2. Why do you study Spanish? Value from 1 (total disagreement) to 7 (total agreement) } \\
\hline & No. & Min. & Max. & Mean & $\begin{array}{l}\text { Std. } \\
\text { Deviation }\end{array}$ & $\begin{array}{l}\text { Correlation } \\
\text { (homogeneity } \\
\text { index) }\end{array}$ \\
\hline Q.II.2.1. Because I need it to live in Spain & 40 & 1 & 7 & 6.53 & 1.09 & 0.54 \\
\hline Q.II.2.2 Because my partner is Spanish & 40 & 1 & 7 & 2.43 & 2.41 & 0.53 \\
\hline Q.II.2.3 Because I have to pass an exam & 40 & 1 & 7 & 3.78 & 2.65 & 0.62 \\
\hline Q.II.2.4 I need it for my residence permit & 40 & 1 & 7 & 2.83 & 2.36 & 0.63 \\
\hline Q.II.2.5 Because I like Spanish & 40 & 3 & 7 & 6.08 & 1.21 & 0.44 \\
\hline Q.II.2.6 Because it is mandatory & 40 & 1 & 7 & 3 & 2.38 & 0.66 \\
\hline Q.II.2.7 To feel more integrated in Spain & 40 & 3 & 7 & 6.33 & 1.25 & 0.47 \\
\hline $\begin{array}{l}\text { Q.II.2.8 Because I have friends who speak } \\
\text { Spanish }\end{array}$ & 40 & 3 & 7 & 5.75 & 1.58 & 0.20 \\
\hline Q.II.2.9 Because I like to learn languages & 40 & 1 & 7 & 6 & 1.59 & 0.54 \\
\hline Q.II.2.10 In order to be able to read better & 40 & 1 & 7 & 6.23 & 1.40 & 0.59 \\
\hline $\begin{array}{l}\text { Q.II.2.11 Better understanding of TV and } \\
\text { radio }\end{array}$ & 40 & 1 & 7 & 6.1 & 1.48 & 0.52 \\
\hline $\begin{array}{l}\text { Q.II.2.12 Because I need it to be able to } \\
\text { work }\end{array}$ & 40 & 1 & 7 & 4.85 & 2.42 & 0.59 \\
\hline \multicolumn{7}{|c|}{ Q.II.3. After studying Spanish I hope ... Value from 1 (total disagreement) to 7 (total agreement) } \\
\hline & No. & Min. & Max. & Mean & $\begin{array}{l}\text { Std. } \\
\text { Deviation }\end{array}$ & $\begin{array}{l}\text { Correlation } \\
\text { (homogeneity } \\
\text { index) }\end{array}$ \\
\hline Q.II.3.1 Being able to relate to more people & 40 & 4 & 7 & 6.50 & 1.01 & 0.57 \\
\hline Q.II.3.2 Relating myself better to my peers & 40 & 3 & 7 & 6.35 & 1.10 & 0.52 \\
\hline Q.II.3.3 Improving studies & 40 & 1 & 7 & 5.58 & 2.04 & 0.74 \\
\hline Q.II.3.4 Improve my CV & 40 & 1 & 7 & 5.60 & 2.01 & 0.81 \\
\hline $\begin{array}{l}\text { Q.II.3.5 Being more prepared for work in } \\
\text { Spain }\end{array}$ & 40 & 1 & 7 & 6.00 & 1.74 & 0.77 \\
\hline $\begin{array}{l}\text { Q.II.3.6 Better understand Spain and the } \\
\text { Spaniards }\end{array}$ & 40 & 3 & 7 & 6.55 & 0.90 & 0.73 \\
\hline Q.II.3.7 Manage myself better in daily life & 40 & 3 & 7 & 6.35 & 1.10 & 0.71 \\
\hline Q.II.3.8 I do not expect anything concrete & 40 & 1 & 7 & 2.63 & 2.16 & 0.43 \\
\hline
\end{tabular}

For the students surveyed, the study of Spanish is an important social tool, since the main objective for which they study Spanish is to interact in the host society. Ranked below other items is finding a good job (Q.II.1.1 with 11.02\%). The latter suggests that either it is not a priority to work because they already have work, or they do not consider that improving their knowledge of Spanish will result in a better job.

Regarding learning Spanish in order to gain access to higher education or for communication with children's teachers, as we know, 11 of the 40 students surveyed had participated in higher education. This reduced their interest in this aim. On the other hand, there were young students with no children who were not concerned with helping children at school. This last question prompted us to think of the need to include in the questionnaire items relating to marital status, number of children, and their ages.

The main reason why the participants studied Spanish (Q.II.2) was because they live in Spain (Q.II.2.1.), the response given by $80 \%$, and Followed by learning for integration in Spain (Q.II.2.7). 
Similarly, responses reveal an instrumental need for SFL learning (Q.II.2.10 and P.II.2.11) related to the development and improvement of certain skills (better reading and understanding of TV and radio). This may be due to the need to be informed and to understand socio-cultural and bureaucratic aspects of live in Spain. A high index of agreement is shown in items Q.II.2.5 and Q.II.2.9, over and above questions of a more administrative nature, such as passing an exam. Therefore, the participants are more concerned with their own language learning than with administrative issues. Note that participants, after learning Spanish, show a higher index of agreement in items Q.II.3.1 (better understand Spain and the Spaniards) and Q.II.3.6 (be able to relate to more people). Again, the social and interpersonal factors appear to be the most relevant among those surveyed.

Block III: Aspects of Teaching Spanish as a second language in the classroom

In this block, we focus on to the habits of students in their study of Spanish, as well as their tastes, needs, or preferences that is summarized in Table 5.

Table 5. Survey Block III data.

\begin{tabular}{|c|c|c|c|c|c|c|}
\hline \multicolumn{7}{|c|}{ BLOCK III. Aspects of teaching Spanish as a second language in the classroom } \\
\hline \multicolumn{7}{|c|}{$\begin{array}{l}\text { Q.III.1. How much time do you devote to studying Spanish? Value from } 0 \text { (total disagreement) to } 7 \text { (total } \\
\text { agreement) }\end{array}$} \\
\hline & No. & Min. & Max. & Mean & $\begin{array}{l}\text { Std. } \\
\text { Deviation }\end{array}$ & $\begin{array}{l}\text { Correlation } \\
\text { (homogeneity } \\
\text { index) }\end{array}$ \\
\hline Q.III.1.1 As long as I can & 40 & 1 & 7 & 5.73 & 1.74 & 0.53 \\
\hline Q.III.1.2 Enough to keep moving well & 39 & 1 & 7 & 5.31 & 1.98 & 0.65 \\
\hline Q.III.1.3 A little time every day & 40 & 1 & 7 & 4.75 & 2.02 & 0.66 \\
\hline $\begin{array}{l}\text { Q.III.1.4 Nothing, because I do not have } \\
\text { much time }\end{array}$ & 40 & 1 & 7 & 3.35 & 2.25 & 0.37 \\
\hline Q.III.1.5 I have not raised it & 39 & 1 & 7 & 2.41 & 1.76 & 0.42 \\
\hline \multicolumn{7}{|c|}{$\begin{array}{l}\text { Q.III.2. From the following statements, rate the importance of these statements from } 1 \text { to } 7(1=\text { not } \\
\text { important, } 7=\text { very important). }\end{array}$} \\
\hline & No. & Min. & Max. & Mean & $\begin{array}{l}\text { Std. } \\
\text { Deviation }\end{array}$ & $\begin{array}{l}\text { Correlation } \\
\text { (homogeneity } \\
\text { index) }\end{array}$ \\
\hline $\begin{array}{l}\text { Q.III.2.1 Understanding what is said in } \\
\text { Spanish }\end{array}$ & 40 & 3 & 7 & 6.28 & 1.20 & 0.86 \\
\hline Q.III.2.2 Speaking to others in Spanish & 40 & 3 & 7 & 6.43 & 1.11 & 0.83 \\
\hline $\begin{array}{l}\text { Q.III.2.3 Understanding what I read in } \\
\text { Spanish }\end{array}$ & 39 & 2 & 7 & 6.28 & 1.21 & 0.87 \\
\hline Q.III.2.4 Being able to write in Spanish & 40 & 2 & 7 & 6.30 & 1.32 & 0.91 \\
\hline Q.III.2.5 Translate into my mother tongue & 40 & 2 & 7 & 5.48 & 1.99 & 0.64 \\
\hline \multicolumn{7}{|c|}{$\begin{array}{l}\text { Q.III.3. The most important thing about a Spanish course as a foreign language is... Value from } 1 \text { to } 7(1= \\
\text { not important, } 7=\text { very important) }\end{array}$} \\
\hline & No. & Min. & Max. & Mean & $\begin{array}{l}\text { Std. } \\
\text { Deviation }\end{array}$ & $\begin{array}{l}\text { Correlation } \\
\text { (homogeneity } \\
\text { index) }\end{array}$ \\
\hline Q.III.3.1 Grammar & 40 & 1 & 7 & 6.05 & 1.52 & 0.62 \\
\hline Q.III.3.2 Pronunciation & 40 & 1 & 7 & 5.68 & 1.95 & 0.74 \\
\hline Q.III.3.3 Vocabulary & 40 & 1 & 7 & 6.05 & 1.52 & 0.79 \\
\hline
\end{tabular}


Table 5. Cont.

\begin{tabular}{|c|c|c|c|c|c|c|}
\hline Q.III.3.4 Reading & 39 & 1 & 7 & 5.54 & 1.76 & 0.72 \\
\hline Q.III.3.5 Writing & 37 & 1 & 7 & 5.65 & 1.90 & 0.81 \\
\hline Q.III.3.6 The culture of the country & 40 & 2 & 7 & 5.63 & 1.41 & 0.55 \\
\hline Q.III.3.7 Communication with others & 40 & 2 & 7 & 6.00 & 1.48 & 0.79 \\
\hline Q.III.3.8 Non-verbal communication & 40 & 1 & 7 & 4.03 & 2.25 & 0.39 \\
\hline \multicolumn{7}{|c|}{$\begin{array}{l}\text { Q.III.4. What kind of activities do you prefer to do in class? Value from } 1 \text { (not important) to } 7 \text { (very } \\
\text { important) }\end{array}$} \\
\hline & No. & Min. & Max. & Mean & $\begin{array}{l}\text { Std. } \\
\text { Deviation }\end{array}$ & $\begin{array}{l}\text { Correlation } \\
\text { (homogeneity } \\
\text { index) }\end{array}$ \\
\hline Q.III.4.1 Grammar activities & 40 & 1 & 7 & 5.80 & 1.64 & 0.63 \\
\hline Q.III.4.2 Vocabulary activities & 38 & 1 & 7 & 5.97 & 1.52 & 0.65 \\
\hline Q.III.4.3 Listening activities & 40 & 1 & 7 & 5.75 & 1.64 & 0.72 \\
\hline $\begin{array}{l}\text { Q.III.4.4 Oral expression and interaction } \\
\text { activities }\end{array}$ & 40 & 2 & 7 & 5.98 & 1.42 & 0.81 \\
\hline Q.III.4.5 Reading comprehension activities & 40 & 2 & 7 & 5.53 & 1.62 & 0.66 \\
\hline $\begin{array}{l}\text { Q.III.4.6 Written expression and } \\
\text { interaction activities }\end{array}$ & 40 & 1 & 7 & 5.60 & 1.57 & 0.52 \\
\hline $\begin{array}{l}\text { Q.III.4.7 Activities relating to Spanish } \\
\text { culture }\end{array}$ & 40 & 1 & 7 & 5.70 & 1.54 & 0.63 \\
\hline \multicolumn{7}{|c|}{ Q.III.5. How do you think you learn Spanish better? Value from 1 to 7 (1 = not important, 7 = important) } \\
\hline & No. & Min. & Max. & Mean & $\begin{array}{l}\text { Std. } \\
\text { Deviation }\end{array}$ & $\begin{array}{l}\text { Correlation } \\
\text { (homogeneity } \\
\text { index) }\end{array}$ \\
\hline Q.III.5.1 Reading & 40 & 3 & 7 & 6.03 & 1.21 & 0.67 \\
\hline Q.III.5.2 Writing & 39 & 3 & 7 & 5.97 & 1.16 & 0.73 \\
\hline Q.III.5.3 Speaking & 40 & 4 & 7 & 6.48 & 1.13 & 0.67 \\
\hline Q.III.5.4 Listening & 40 & 4 & 7 & 6.30 & 0.91 & 0.73 \\
\hline Q.III.5.5 Playing & 40 & 1 & 7 & 5.55 & 1.97 & 0.61 \\
\hline \multicolumn{7}{|c|}{$\begin{array}{l}\text { Q.III.6. I like the classes at the OSL in Granada because... Value from } 1 \text { (total disagreement) to } 7 \text { (total } \\
\text { agreement) }\end{array}$} \\
\hline & No. & Min. & Max. & Mean & $\begin{array}{l}\text { Std. } \\
\text { Deviation }\end{array}$ & $\begin{array}{l}\text { Correlation } \\
\text { (homogeneity } \\
\text { index) }\end{array}$ \\
\hline $\begin{array}{l}\text { Q.III.6.1 Because I can express myself } \\
\text { freely }\end{array}$ & 40 & 3 & 7 & 5.85 & 1.44 & 0.63 \\
\hline Q.III.6.2 Because they make me feel good & 40 & 3 & 7 & 5.68 & 1.38 & 0.65 \\
\hline $\begin{array}{l}\text { Q.III.6.3 Because I can speak about my } \\
\text { country }\end{array}$ & 40 & 1 & 7 & 3.63 & 2.19 & 0.60 \\
\hline $\begin{array}{l}\text { Q.III.6.4 Because the teacher considers my } \\
\text { opinion }\end{array}$ & 40 & 2 & 7 & 5.50 & 1.59 & 0.74 \\
\hline Q.III.6.5 Because I can speak about myself & 40 & 1 & 7 & 4.23 & 1.90 & 0.69 \\
\hline Q.III.6.6 Because it is an easy language & 40 & 1 & 7 & 3.53 & 2.06 & 0.65 \\
\hline Q.III.6.7 Because it is fun & 40 & 1 & 7 & 5.03 & 1.66 & 0.54 \\
\hline
\end{tabular}


From these results, we can conclude that those surveyed do not devote time to studying Spanish (Q.III.1.1), although it would have been useful to have a specific open question in which they indicated the weekly amount of time they dedicated to studying Spanish.

In relation to the skills that predominate among those surveyed, oral expression and interaction was found (Q.III.2.2), and at the same time, the social element of learning Spanish is prevalent, as was the case in previous questionnaire items.

The elements of teaching-learning of Spanish in the classroom with the highest index of importance were grammar and vocabulary (Q.III.3.1 and Q.III.3.3), followed by communicating with others. Related to this, the most important activities to develop in the classroom were oral (Q.III.4.4.), followed by vocabulary and grammar activities (Q.III.4.1 and Q.III.4.2). Thus, the order of importance that the Spanish students of the OSL of Granada attached to classroom activities placed oral expression first, followed by listening, reading, writing, and ultimately, activities based on play.

Item Q.III.6. was used to evaluate the Spanish classes in the OSL of Granada. Free expression, feeling good, and having one's opinion valued have the highest averages, indicating affective variables related to mood and self-esteem (Arnold 2000).

\section{Discussion}

The aggregate survey results from this exploratory study offer us a glimpse into a program that caters to quite a wide range of types of adult learners, and this will undoubtedly serve to improve the ability of the OSL of Granada to best serve the students. These data are complemented by participant observation. Thus, the data in block I have allowed us to trace a complete and detailed profile of the students studying Spanish at this language school (age, work, origin, time spent studying Spanish, mother tongue, etc.), highlighting some important factors, such as their level of education, which turns out to be university for many. This contrasts with assumptions about students of SL on non-intensive programs. The ethnic, cultural, linguistic, and social heterogeneity of those on the program create challenges for any teacher. There is no doubt that this diversity affects the kind of activities that can be carried out in class, the degree of student involvement in them, and relationships among students and with the teacher. This is directly related to the students' beliefs about what teaching in the classroom should be like, fostered by their previous educational experience. Thus, we observe in the data that the top preferences for classroom activities are oral expression and interaction, followed by vocabulary and grammatical activities; however, the observation data reveal a more complex reality. Those who favor oral activities are Arabic speakers, especially those with less than a university education. This may be related to use of a different writing system in their native language. Brazilians and Italians also favor oral activities, most likely due to the linguistic similarity between Spanish and their mother tongue. The students who prefer to focus on grammar are the Eastern European students.

Linguistic background-not only the mother tongue but also knowledge of other languages-is also important for several reasons, as we see in both the questionnaire and observation data. Firstly, the writing system is important, and when the student's native language system differs from Spanish, is not based on the Roman alphabet, and they do not know another language which uses the alphabet, they may have a range of difficulties with reading and writing activities. Such students, therefore, tend to prefer oral activities over written ones. Secondly, the student's native language phonology and the phonology of other languages they know affect both their comprehension of Spanish as well as what they express orally in terms of intelligibility and fluency. Thirdly, with regard to morphosyntax, the mother tongue - or any other foreign language they know — can also favor or hinder their learning of Spanish by leading to errors that may eventually fossilize in the student's interlanguage. Fourthly, related to pragmatic issues, students will tend to behave communicatively according to the models of behavior of their own language community, which in some cases may hinder communication, such as aspects of interactive rituals, cultural guidelines, intonation, proximity, and body language.

In addition to these data, what emerges from block II is the social importance that learning Spanish has for our foreign students, followed by institutional and interpersonal learning, as also shown by 
ethnographic work carried out in the center. In this sense, over and above improving their employment situation is the need to cover daily life requirements as basic as that of going shopping in a new country, as well as those that are more complex, such as the bureaucratic processes involved in managing official documentation or health care. We also observe how the developments of different skills (speaking, listening, reading, and writing) are subordinated to the social needs of our students.

Block III, linked to aspects of teaching, presents grammar and vocabulary as most important for our students, implying that they have a learning style typical of the traditional method. However, they also attach great importance to communication with others and to the interpersonal and inter-relational use of their new language.

With all the data extracted and analyzed from the questionnaire and the observation, we have sufficient information to determine the needs of immigrant and refugee students, to establish a balance between external curricular design (as set by others) and internal ways of doing things that arise in the classroom, and to offer curricular adaptations that are appropriate for this sort of group of students. We now have empirical data applicable to teaching practice and to the organization of our educational center itself, which has led us to rethink various aspects of the courses at the OSL.

\section{Conclusions}

This exploratory research has provided a profile of students at the OSL in Granada, characterized by diversity of origin as well as by educational background. These findings are helping in the implementation of specific measures for the classroom, and at the same time are motivating greater interactions between agents, including program managers in Granada and throughout Andalusia in the network of public institutions that provide for adults. These changes aim to promote, in short, the autonomy and integration of immigrant and refugee students in Spain. The challenges in relation to this student body are, as we have pointed out, to address how Spanish is taught to adult residents in Granada as well as greater Spain, with the caveat that further exploratory research should be carried out in other OSLs to corroborate our findings. Finally, in relation to the teaching staff, our findings allow us to imagine which training activities are necessary to support student's social and linguistic integration into Spanish society.

Author Contributions: The present project was designed by M.I.A.P. and J.P.C.G. Conceptualization, M.I.A.P. and J.P.C.G.; methodology, M.I.A.P. and J.P.C.G.; formal analysis, M.I.A.P. and J.P.C.G.; investigation, M.I.A.P. and J.P.C.G.; data curation, M.I.A.P. and J.P.C.G.; writing-original draft preparation, M.I.A.P. and J.P.C.G.; writing—review and editing M.I.A.P. and J.P.C.G.; supervision, F.J.G.M.

Funding: This research received no external funding.

Conflicts of Interest: The authors declare no conflicts of interest.

Appendix A ${ }^{7}$

\begin{tabular}{l}
\hline BLOCK I. Control Information \\
\hline Q.I.1. Course carried out at the OSL in Granada \\
\hline Q.I.2. Gender \\
\hline Q.I.3. Age \\
\hline Q.I.4. Nationality \\
\hline Q.I.5. Level of studies \\
\hline Q.I.6. What do you do in Spain? \\
\hline Q.I.7. Type of family from the cultural/linguistic point of view \\
\hline
\end{tabular}

$7 \quad$ The original survey was in Spanish to the students. 
Q.I.8. What is your mother tongue?

Q.I.9. What other foreign languages do you know and can you use these fluently?

Q.I.10. Since you left your country, in how many countries have you resided?

Q.I.11. How long have you been residing in Spain?

Q.I.12. How long have you been studying Spanish?

Q.I.13. Did you study Spanish in your country of origin?

BLOCK II. Learning Spanish as second language

Q.II.1. Why do you think you need to learn Spanish? (Value from 1 (total disagreement) to 7 (total agreement))

Q.II.1.1 I think Spanish is convenient in order to find a good job

Q.II.1.2 I consider that Spanish is useful to be able to relate to other people who live in this country

Q.II.1.3 I consider that Spanish is convenient to be able to study (yourself, your children, your relatives and acquaintances)

Q.II.1.4 I consider that Spanish is convenient to understand doctors and nurses.

Q.II.1.5 I consider that Spanish is useful to be able to go shopping

Q.II.1.6 I consider that Spanish is useful to be able to manage my papers and go to the administration

Q.II.1.7 I consider that Spanish is suitable for higher education

Q.II.1.8 I believe that Spanish is useful for me to understand my son/daughter's teacher

Q.II.2. Why do you study Spanish? (Value from 1 (total disagreement) to 7 (total agreement))

Q.II.2.1. Because I need it to live in Spain

Q.II.2.2 Because my partner is Spanish

Q.II.2.3 Because I have to pass an exam

Q.II.2.4 I need it for my residence permit

Q.II.2.5 Because I like Spanish

Q.II.2.6 Because it is mandatory

Q.II.2.7 To feel more integrated in Spain

Q.II.2.8 Because I have friends who speak Spanish

Q.II.2.9 Because I like to learn languages

Q.II.2.10 In order to be able to read better

Q.II.2.11 Better understanding of TV and radio

Q.II.2.12 Because I need it to be able to work

Q.II.3. After studying Spanish I hope ... (Value from 1 (total disagreement) to 7 (total agreement))

Q.II.3.1 Being able to relate to more people

Q.II.3.2 Relating myself better to my peers

Q.II.3.3 Improving studies

Q.II.3.4 Improve my CV

Q.II.3.5 Being more prepared for work in Spain

Q.II.3.6 Better understand Spain and the Spaniards

Q.II.3.7 Manage myself better in daily life

Q.II.3.8 I do not expect anything concrete 
BLOCK III. Aspects of teaching Spanish as a foreign language in the classroom

Q.III.1. How much time do you devote to studying Spanish? (Value from 0 (total disagreement) to 7 (total agreement))

Q.III.1.1 As long as I can

Q.III.1.2 Enough to keep moving well

Q.III.1.3 A little time every day

Q.III.1.4 Nothing, because I do not have much time

Q.III.1.5 I have not raised it

Q.III.2. From the following statements, rate the importance of these statements from 1 to $7(1=$ not important, 7 = very important)].

Q.III.2.1 Understanding what is said in Spanish

Q.III.2.2 Speaking to others in Spanish

Q.III.2.3 Understanding what I read in Spanish

Q.III.2.4 Being able to write in Spanish

Q.III.2.5 Translate into my mother tongue

P.III.3. The most important thing about a Spanish course as a foreign language is... Value from 1 to 7 $(1=$ not important, $7=$ very important $)$

Q.III.3.1 Grammar

Q.III.3.2 Pronunciation

Q.III.3.3 Vocabulary

Q.III.3.4 Reading

Q.III.3.5 Writing

Q.III.3.6 The culture of the country

Q.III.3.7 Communication with others

Q.III.3.8 Non-verbal communication

Q.III.4. What kind of activities do you prefer to do in class? Value from 1 (not important) to 7 (very important)

Q.III.4.1 Grammar activities

Q.III.4.2 Vocabulary activities

Q.III.4.3 Listening activities

Q.III.4.4 Oral expression and interaction activities

Q.III.4.5 Reading comprehension activities

Q.III.4.6 Written expression and interaction activities

Q.III.4.7 Activities relating to Spanish culture

Q.III.5. How do you think you learn Spanish better? Value from 1 to $7(1=$ not important, $7=$ important)

Q.III.5.1 Reading

Q.III.5.2 Writing

Q.III.5.3 Speaking

Q.III.5.4 Listening

Q.III.5.5 Playing 
Q.III.6. I like the classes at the OSL in Granada because... (value from 1 (total disagreement) to 7 (total agreement))

Q.III.6.1 Because I can express myself freely

Q.III.6.2 Because they make me feel good

Q.III.6.3 Because I can speak of my country

Q.III.6.4 Because the teacher considers my opinion

Q.III.6.5 Because I can speak of myself

Q.III.6.6 Because it is an easy language

Q.III.6.7 Because with fun

\section{References}

Angrosino, Michael. 2012. Etnografía y observación participante en Investigación Cualitativa. Madrid: Morata.

Arnold, Jane. 2000. La Dimensión afectiva en el aprendizaje de idiomas. Madrid: Edinumen.

Asensio Pastor, Margarita I. 2016. La literatura en el proceso de inmersión lingüística por parte de alumnos inmigrantes. Revista Fuentes 18: 197-208. [CrossRef]

Asensio Pastor, Margarita I. 2018. Enseñar español como Segunda Lengua a alumnos de Educación Infantil: Retos y orientaciones metodológicas. Doblele. Revista de lengua y literatura 4: 108-21. [CrossRef]

Capstick, Tony, and Marie Delaney. 2017. Language for Resilience. The role of Language in Enhancing the Resilience of Syrian Refugees and Host Communities. Available online: https://www.britishcouncil.org/sites/default/files/ language-for-resilience-report-en.pdf (accessed on 1 April 2019).

Carmona García, Juan Pablo. 2017. La formación del profesorado de español para inmigrantes en las Escuelas Oficiales de Idiomas de Andalucía. In La formación de los docentes de español para inmigrantes en distintos contextos educativos. Edited by Dimitrinka Níkleva. Berna: Peter Lang, pp. 321-51.

Carmona García, Juan Pablo. 2018. La enseñanza de E/LE a inmigrantes en las Escuelas Oficiales de Idiomas de Andalucía: Retos y propuestas. Doblele. Revista de lengua y literatura 4: 122-39. [CrossRef]

Chadwik, Adiran, and Amin Awad. 2016. Language for Resilience: Supporting Syrian Refugees. London: British Council.

Díaz-Corralejo Conde, Joaquín. 2001. Reflexiones sobre el interculturalismo en la enseñanza de las lenguas. Actas de las Jornadas sobre la enseñanza del español para inmigrantes y refugiados. Didáctica (Lengua y Literatura) 7: 321-31.

García Marcos, Francisco Joaquín. 2002. Lenguaje e Inmigración (I). Sociolingüística e inmigración. Granada: Método. García Marcos, Francisco Joaquín. 2018. La trastienda de la enseñanza de lenguas extranjeras. Granada: Comares.

García Ortiz, Eva María, and Victoria Khraiche Ruiz-Zorrilla. 2013. Un caso extremo de clase plurilingüe y heterogénea. Inmigrantes refugiados. Revista Nebrija de Lingüística Aplicada a la Enseñanza de Lenguas 13. Available online: https://www.nebrija.com/revista-linguistica/files/articulosPDF/articulo_5322d2ba163f4.pdf (accessed on 1 April 2019).

García Parejo, Isabel. 2003. Los cursos de «español para inmigrantes» en el contexto de la educación de personas adultas. Carabela 53: 45-64.

Griffin, Kim. 2005. Lingüística aplicada a la enseñanza del español como 2/L. Madrid: Arco/Libros.

Hair, Joseph F., Rolph E. Anderson, Ronald L. Tatham, and William C. Black. 1999. Análisis Multivariantes. Madrid: Prentice Hall Iberia.

Hayward, Maria. 2007. Applying Post-Critical Approaches to Refugees-Centred Education. Master degree of Arts (Applied Language Studies). Master thesis, AUT University, Auckland, New Zealand. Available online: http://aut.researchgateway.ac.nz/bitstream/handle/10292/221/HaywardM.pdf?sequence= (accessed on 1 April 2019).

Hernández García, María Teresa, and Félix Villalba Martínez. 1995. Las clases de lengua y cultura para inmigrantes y refugiados. Didáctica 7: 425-32.

Hernández García, María Teresa, and Félix Villalba Martínez. 2003. Análisis descriptivo de materiales didácticos para la enseñanza del español (L2) a inmigrantes. Carabela 53: 133-59. 
Hernández García, María Teresa, and Félix Villalba Martínez. 2010. Perspectivas y líneas de trabajo en la enseñanza de español a inmigrantes. MarcoEle 10. Available online: http://marcoele.com/descargas/expolingua_2006. villalba-hernandez.pdf (accessed on 1 April 2019).

Hernández Sacristán, Carlos, and Ricard Morant Marco. 1997. Lenguaje y emigración. Valencia: Universidad de Valencia.

Instituto Nacional de Estadística. 2018. Cifras de Población (CP) a 1 de julio de 2018 Estadística de Migraciones (EM). Primer semestre de 2018. Available online: https://www.ine.es/prensa/cp_j2018_p.pdf (accessed on 1 April 2019).

Jefatura del Estado. 2006. Ley Orgánica 2/2006, de 3 de mayo, de Educación. BOE, 106, de 4 de mayo de 2006. Available online: https://www.boe.es/buscar/act.php?id=BOE-A-2006-7899 (accessed on 1 April 2019).

Jefatura del Estado. 2009. Ley 12/2009, de 30 de octubre, reguladora del derecho de asilo y de la protección subsidiaria (BOE Núm. 263 de 31 de octubre de 2009). Available online: https://www.boe.es/buscar/act.php? id=BOE-A-2009-17242 (accessed on 1 April 2019).

Jefatura del Estado. 2017. Real Decreto 1041/2017, de 22 de diciembre, por el que fijan las exigencias mínimas del nivel básico a efectos de certificación, se establece el currículo básico de los niveles Intermedio B1, Intermedio B2, Avanzado C1, y Avanzado C2, de las Enseñanzas de idiomas de régimen especial reguladas por la Ley Orgánica 2/2006, de 3 de mayo, de Educación, y se establecen las equivalencias entre las Enseñanzas de idiomas de régimen especial reguladas en diversos planes de estudios y las de este real decreto. BOE, 311, de 23 de diciembre de 2017. Available online: https://www.boe.es/buscar/doc.php?id=BOE-A-2017-15367 (accessed on 1 April 2019).

Junta de Andalucía Consejería de Educación. 2005. Decreto 196/2005, de 13 de septiembre, por el que se aprueba el Reglamento Orgánico de los Centros de Educación Permanente. Available online: https: //www.juntadeandalucia.es/boja/2005/189/6 (accessed on 1 April 2019).

Junta de Andalucía Consejería de Educación. 2007. Orden de 18 de octubre de 2007, por la que se desarrolla el currículo correspondiente a las enseñanzas de idiomas de régimen especial en Andalucía. BOJA, 224, de 14 de noviembre de 2007. Available online: https://www.juntadeandalucia.es/boja/2007/224/4 (accessed on 1 April 2019).

Junta de Andalucía Consejería de Educación. 2012a. Orden de 20 de abril de 2012, por la que se regulan los criterios y procedimientos de admisión del alumnado en las Escuelas Oficiales de Idiomas de la Comunidad Autónoma de Andalucía. BOJA, 86, 4 de mayo de 2012. Available online: https://www.juntadeandalucia.es/boja/2012/86/2 (accessed on 1 April 2019).

Junta de Andalucía Consejería de Educación. 2012b. Decreto 15/2012, de 7 de febrero, por el que se aprueba el Reglamento Orgánico de las Escuelas Oficiales de Idiomas en la Comunidad Autónoma de Andalucía. BOJA, 34, 20 de febrero de 2012. Available online: https://www.juntadeandalucia.es/boja/2012/34/1 (accessed on 1 April 2019).

Junta de Andalucía Consejería de Educación. 2018. Instrucción 12/2018, de 4 de septiembre, de la Dirección General de Ordenación Educativa sobre la Ordenación y el Currículo de las Enseñanzas de Idiomas de Régimen Especial en la Comunidad Autónoma de Andalucía para el curso 2018/2019. Available online: http://www.juntadeandalucia.es/educacion/portals/abaco-portlet/content/e45f256d-6bfb-45a3-bd73fa6bbfdfc3af (accessed on 1 April 2019).

Kleinmann, Howard. 1984. Undertanding refugee Second Language Learning. The JALT Journal 6: 209-20.

Larrañaga Domínguez, Ainhoa. 2003. Aproximación a una bibliografía sobre la enseñanza del español como segunda lengua/lengua extranjera a inmigrantes. Carabela 53: 161-76.

Larsen-Freeman, Diane, and Michael Long. 1991. Theories in Second Language Acquisition. London: Longman.

Mateo García, María Victoria. 1995. Enseñanza de español a inmigrantes. Datos empíricos y propuestas teóricas. Revista de Estudios de Adquisición de la Lengua Española 3: 117-27.

McMillan, James H., and Sally Schumacher. 2011. Investigación educativa. Una introducción conceptual. Madrid: Pearson Eudcación. Addison Wesley Longman.

Ministerio del Interior. 2016. Anuario de estadísticas del Ministerio del Interior, 2016. Available online: http://www.interior.gob.es/documents/642317/1204854/Anuario+Estadistico+2016.pdf/6c02fffa-93c44838-b1d5-a882971c2cdc (accessed on 1 April 2019).

Miquel López, Lourdes. 1995. Reflexiones previas sobre la enseñanza de E/LE a inmigrantes y refugiados. Didáctica 7: 241-54. 
Miquel López, Lourdes. 2003. Consideraciones sobre la enseñanza de español lengua extranjera a inmigrantes. Carabela 53: 5-24.

Moreno García, Concha. 2004. La enseñanza de español como lengua extranjera en contexto escolar. Un enfoque intercultural de la enseñanza de la lengua. Madrid: Ministerio de Educación and Ciencia/Catarata.

Muñoz, Carmen. 2002. Aprender Idiomas. Barcelona: Paidós.

Muñoz López, Belén. 2004. La enseñanza del español a inmigrantes en el marco institucional. In Vademécum para la formación de profesores. Enseñar español como segunda lengua (L2) / Lengua extranjera (LE). Edited by Joaquín Sánchez Lobato and Isabel Santos Gargallo. Madrid: SGEL, vol. 1, pp. 205-23.

Níkleva, Dimitrinka, ed. 2014. El reto de atender a los alumnos inmigrantes en la sociedad de acogida. Madrid: Síntesis.

Níkleva, Dimitrinka, ed. 2017. La formación de los docentes de español para inmigrantes en distintos contextos educativos. Bern: Peter Lang.

Pastor Cesteros, Susana. 2004. Aprendizaje de segundas lenguas: lingüística aplicada a la enseñanza de idiomas. Alicante: Servicio de Publicaciones Universidad de Alicante.

Richards, Jack C., and Theodore S. y Rodgers. 2003. Enfoques y métodos en la enseñanza de idiomas. Madrid: Cambridge University Press.

Salazar García, Ventura. 2004. Adquisición de segundas lenguas. Granada: Método.

Santos Gargallo, Isabel. 1999. Lingüística aplicada a la enseñanza-aprendizaje del español como lengua extranjera. Madrid: Arco/Libros.

Slagter, Peter Jan. 1994. Fiabilidad y validez en tests de lengua. A propósito de un test de elección múltiple de español como lengua extranjera. REALE 1: 137-56.

UN. 1967. Protocolo sobre el Estatuto de los Refugiados. Available online: http://www.acnur.org/fileadmin/scripts/ doc.php?file=fileadmin/Documentos/BDL/2001/0003 (accessed on 1 April 2019).

United Nations High Commissioner for Refugees-UNHCR-. 2017. Tendencias Globales de 2016. Available online: http://www.acnur.org/recursos/estadisticas/tendencias-globales-2016/ (accessed on 1 April 2019).

United Nations-UN-. 1951. Convenio sobre el Estatuto de los Refugiados. Available online: http://www.acnur. org/fileadmin/scripts/doc.php?file=fileadmin/Documentos/BDL/2001/0005 (accessed on 1 April 2019).

Villalba Martínez, Félix, and Maite Hernández García. 2004. Manifiesto de Santander: La enseñanza de segundas lenguas a inmigrantes. Available online: https://cvc.cervantes.es/ensenanza/biblioteca_ele/inmigracion/documentos/ manifiesto.htm (accessed on 1 April 2019).

(C) 2019 by the authors. Licensee MDPI, Basel, Switzerland. This article is an open access article distributed under the terms and conditions of the Creative Commons Attribution (CC BY) license (http://creativecommons.org/licenses/by/4.0/). 